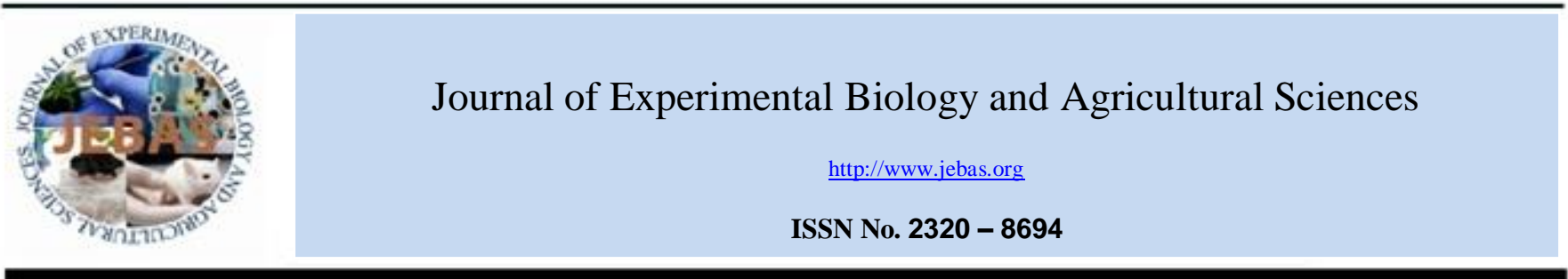

\title{
EFFECT OF TILLAGE AND MULCHING ON SOIL WATER EROSION IN LINSINLIN WATERSHED, CENTRE OF BENIN
}

\author{
AKPLO Tobi Moriaque ${ }^{1}$, KOUELO ALLADASSI Félix ${ }^{1 *}$, HOUNGNANDAN Pascal $^{1}$, \\ BENMANSOUR Moncef ${ }^{2}$, RABESIRANANA Naivo ${ }^{3}$, MABIT Lionel ${ }^{4}$, AHOGLE AGASSIN \\ Martinien Arcadius ${ }^{1}$, ALOHOUTADE Finagnon Mathieu ${ }^{1}$
}

\footnotetext{
${ }^{1}$ Laboratory of Soil Microbiology and Microbial Ecology, Faculty of Agronomic Sciences, University of Abomey-Calavi, 01 BP 526 Cotonou (BENIN)

${ }^{2}$ Centre National des Energies, Sciences et Techniques Nucléaires (CNESTEN), Rabat, Maroc

${ }^{3}$ Institut National des Sciences et Techniques Nucléaires (INSTN), Antananarivo, Madagascar

${ }^{4}$ SWMCNS, Joint FAO/IAEA, Division of Nuclear Techniques in Food and Agriculture, Vienna-Seibersdorf
}

Received - June 15, 2017; Revision - August 19, 2017; Accepted - September 09, 2017

Available Online - September 10, 2017

DOI: http://dx.doi.org/10.18006/2017.5(4).515.524

\section{KEYWORDS \\ Isohypse tillage \\ Mulching \\ water erosion \\ Watershed \\ Djidja}

\section{* Corresponding author}

E-mail: felix.kouelo@gmail.com (KOUELO ALLADASSI Félix1)

Peer review under responsibility of Journal of Experimental Biology and Agricultural Sciences.

Production and Hosting by Horizon Publisher India [HPI] (http://www.horizonpublisherindia.in/).

All rights reserved.

\begin{abstract}
Soils degradation in Benin is most commonly reported thread for the agricultural production and this situation became more crucial in the Centre of Benin. This study has been carried out to evaluate the contribution of farmer's soil conservation practices to combat soil erosion in the agricultural watershed of Linsinlin. A field experiment was conducted on loamy-sand soil using Fisher Block design under researcher management. The factors which testified during study were tillage and mulching. The "Runoff plot" system was installed to collect erosion data. Three rainfall episodes viz, June 15, 19 and 27, 2016 with 52, 27 and $57 \mathrm{~mm}$ of water were used for the data collection. Rain distribution was measured for each rainy episode using a rain gauge. These three rainy episodes constitute a repetition. Results of study revealed that tillage and mulching treatment significantly decrease runoff, soil loss and nutrients loss (nitrogen, available phosphorus, potassium, magnesium). In case of nutrient lose, highest amount of nitrogen and potassium were lost. The interactive effect of tillage system and mulching was significant on runoff, soil and nutrient loss. The treatment combining isohypse ridging with mulching practice reduced total runoff from $6.27 \%$ to $0 \%$, soil loss $2028 \mathrm{~kg} \cdot \mathrm{ha}^{-1}$. rain $^{-1}$ to $0 \mathrm{~kg}$. ha ${ }^{-1} \cdot \mathrm{rain}^{-1}$ and
\end{abstract}

All the article published by Journal of Experimental Biology and Agricultural Sciences is licensed under a Creative Commons Attribution-NonCommercial 4.0 International License Based on a work at www.jebas.org.

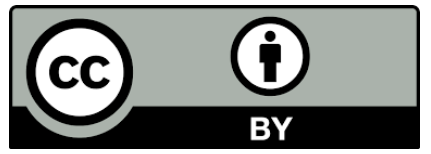


nutrient loss (from $4.32 \mathrm{~kg}$. rain ${ }^{-1}$ to $0 \mathrm{~kg}$. rain $^{-1}$ for total nitrogen, from $0.17 \mathrm{~kg}$.rain ${ }^{-1}$ to $0 \mathrm{~kg}$.rain ${ }^{1}$ for available phosphorus, from $4.38 \mathrm{~kg} \cdot$ rain $^{-1}$ to $0 \mathrm{~kg} \cdot \mathrm{rain}^{-1}$ for potassium, from $3.32 \mathrm{~kg} \cdot \mathrm{rain}^{-1}$ to $0 \mathrm{~kg} \cdot$ rain $^{-1}$ for magnesium). Particulate organic matter, clay and sand fraction were more lost through water erosion on the watershed of Linsinlin.

\section{Introduction}

Chemical and physical degradation affects most of the present agricultural land in Africa (Henao \& Baanante, 1999). The soils have poor nutrient retention capacity, and many are heavily leached and eroded. In tropical areas, rainfall also accelerated erosion due to the low vegetation density (Bationo et al., 2004). Soil erosion is a big threatens for the agricultural productivity, food security and environmental sustainability (Kurothe et al., 2014), this condition became more serious in African continent and erosion affects $72 \%$ productivity. The nutrient lost is 2.5 times higher as compared to remaining soil (Benmansour et al., 2006). The dynamics of agro-systems and agrarian structures in the central agro-ecological zone of Benin has led to a negative evolution of soil (Agossou \& Igué, 2002). Under population pressure (3.5\% as growth rate), fallow practice is greatly reduced or even suppressed in favor of continuous cropping systems, overexploitation of soils without organic or mineral fertilizers. These poor practices results in nutrient depletion, a significant decrease of soil organic matter pool, changes in the nitrogen cycle (Dabin, 1956), runoff, soil erosion and soil acidification. Thus, crop yields and the sustainability of cropping systems are compromised. Under the cover of natural vegetation, soil erosion is non-existent or minimal. With the removal of vegetation cover and fallow, inherent fertility is drastically reduced and accelerated erosion (Nyakatawa et al., 2001; Isikwue, 2005; Pandey et al., 2007). Further, Kouelo (2016) reported an average annual soil loss of 17.69 t.ha $^{-1} \cdot \mathrm{an}^{-1}$ over the last 50 years at the Lokogba watershed in Aplahoué. Agricultural practices must ensure the sustainability of agricultural systems. Tillage, when properly carried out, is an excellent means of combating water erosion. Residues of plants left on the soil surface play a fundamental role in soil protection against erosion (Mazarei \&Ahangar, 2013). The objectives of this study were to determine how various types of tillage and mulching affects soil erosion in centre of Benin and to use the results to identify sustainable land management practices that would reduce soil erosion.

\section{Materials and Methods}

\subsection{Study area}

The experiment was carried out at Linsinlin watershed (latitude $7^{\circ}$ $20^{\prime} 46$ ' North; longitude $1^{\circ} 56$ ' 8" East and $190 \mathrm{~m}$ above mean sea level) at Djidja municipality in Benin from May 29, 2016 to August 31, 2016 (Figure 1). The study area is situated on the Precambrian basement of the Peneplaine Cristalline base rocks as

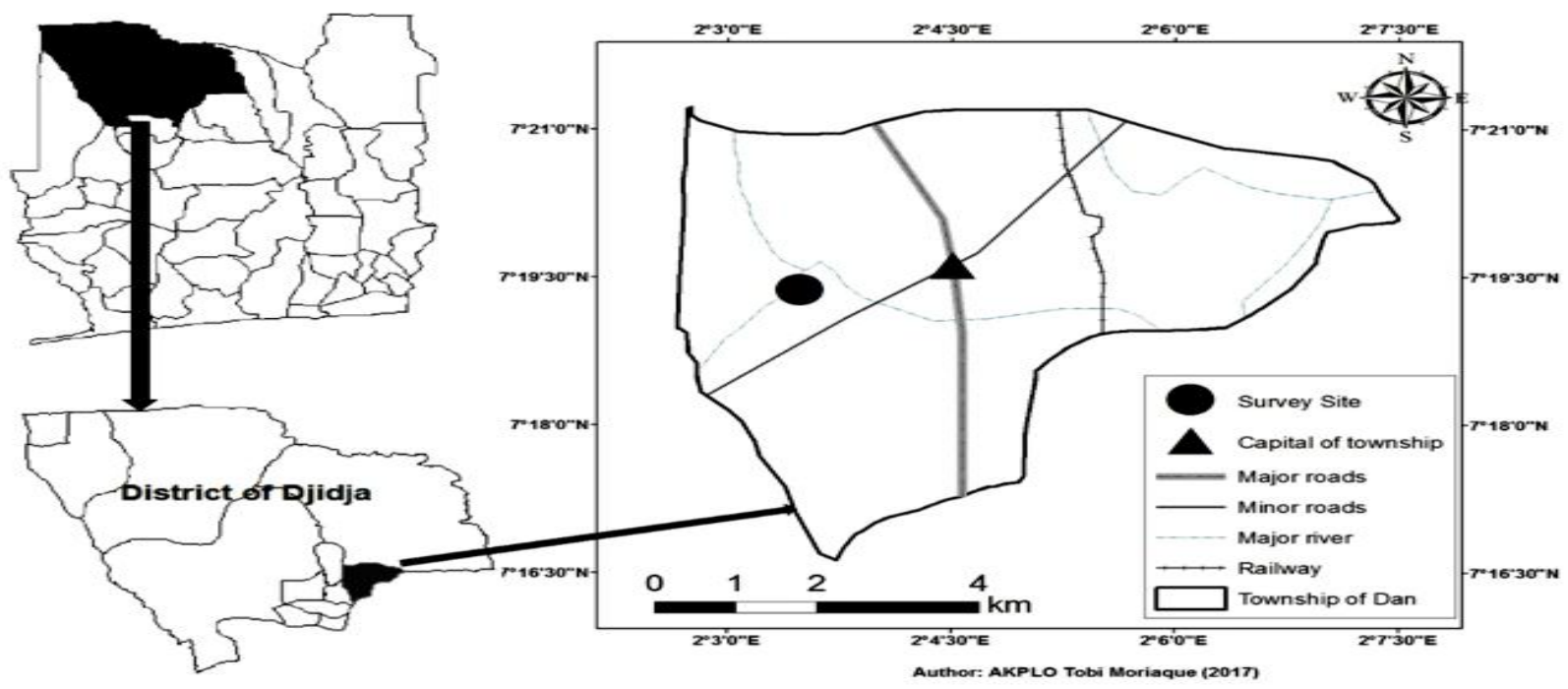

Figure 1 : Geographical location and physical map of the study area 
Table 1 Chemical characteristics of study area soil

\begin{tabular}{|c|c|c|c|c|c|c|}
\hline \multirow{2}{*}{ Depth $(\mathrm{cm})$} & \multirow{2}{*}{ Nitrogen $(\%)$} & \multirow{2}{*}{$\begin{array}{l}\text { Available phosphorus } \\
\qquad(\mathrm{ppm})\end{array}$} & \multirow{2}{*}{$\begin{array}{c}\text { Organic matter } \\
(\%)\end{array}$} & \multirow{2}{*}{$\begin{array}{c}\text { CEC (méq } / 100 \mathrm{~g} \text { de } \\
\text { sol) }\end{array}$} & \multicolumn{2}{|c|}{$\mathrm{pH}$} \\
\hline & & & & & $\mathrm{KCl}$ & Eau \\
\hline $0-20$ & 0.11 & 74.62 & 0.91 & 25.94 & 5.10 & 5.75 \\
\hline $20-40$ & 0.11 & 74.16 & 0.69 & 32.81 & 4.93 & 5.78 \\
\hline
\end{tabular}

embrechites and granites (Igué, 2000). The soil of the study area is ferruginosols type (Baize \& Girard, 2009). Major chemical properties of the study area soil are presented in Table 1 . The soil of the field experiment have a poor chemical properties. Especially, the low soil organic matter indicate a higher degree of soil degradation of this watershed. Linsinlin has a bimodal rainfall distribution with a long rainy season from March to July and a short rainy season from September to November. The annual rainfall of the study area is $1200 \mathrm{~mm}$ and the average temperature is around $28^{\circ} \mathrm{C}$, while the average slope in the study site is $5 \%$.

\subsection{Experimental design}

The experiment design used is known as "Runoff plot". The erosion plots system (Figure 2) includes a rain gauge and 7

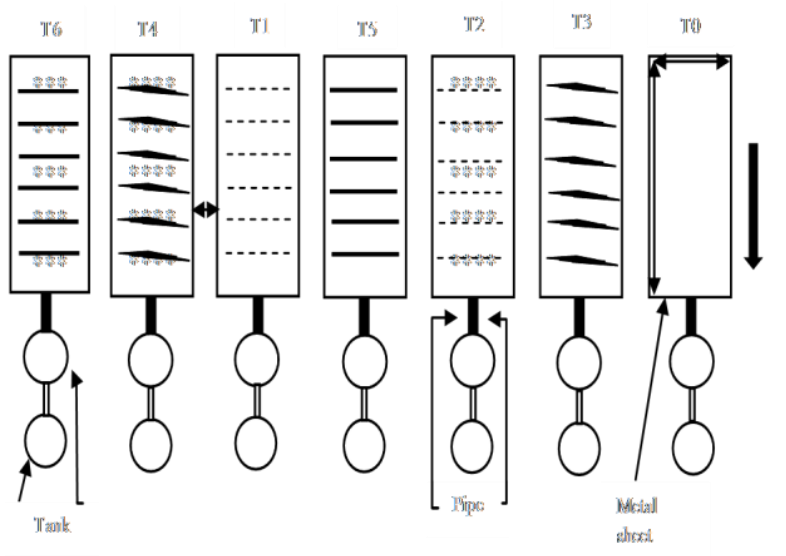

Figure 2 : Runoff design used in this study

erosion plots of $21 \mathrm{~m}^{2}$ (6 treatments combining tillage and mulching and 1 control plot), isolated from the outside by metal sheets embedded in the ground at the edge of the plots. Downstream, a receiving system directs runoff water and eroded soil to a storage system consisted by two tank. The first tank was connected to each plot by a PVC pipe with $40 \mathrm{~mm}$ in diameter. It is pierced in its upper part with 8 identical holes and connected to the second by a PVC pipe of $20 \mathrm{~mm}$ diameter. Using this system, it was possible to determine the runoff rate, the fine suspended soil loss (fraction able to migrate over a long distance) and the coarse soil particle loss (short-distance crawling). This erosion measurement on small plots allows to weigh various factors (vegetation, slope, soil, cultural practice) which involved in water erosion, but it is only sheet erosion, the one that interests mainly agronomists and pedologists. Three rainfall episodes i.e. June 15, 2016, June 19, 2016 and June 27, 2016 with $52 \mathrm{~mm}, 27 \mathrm{~mm}$ and $57 \mathrm{~mm}$ rainfall were used for the data collection. Rain amount was measured for each rainy episode using a rain gauge. Each rainy episode constitutes a repetition. Various treatments used in this study were Control (T0), No tillage + without mulch (T1), No tillage + with mulch (T2), Minimum tillage + without mulch (T3), Minimum tillage + with mulch (T4), Isohypse ridging + without mulch (T5) and Isohypse ridging + with mulch (T6).

\subsection{Data collection}

The data collected were runoff volume, soil loss, nutrient loss, mineral and organic constituents of soil lost.

\subsubsection{Runoff volume}

After each rain over 30 minutes, runoff was collected in the tanks with the installed receiving system. The runoff volume (Vr) is calculated by the following formulae (Roose,1967):

$$
\mathrm{Vr}=\mathrm{V} 1+(8 \times \mathrm{V} 2)
$$

whereas: $\mathrm{V} 1=$ Volume of runoff in the first tank and V2 = Volume of runoff in the second tank.

\subsubsection{Soil loss}

Sediments deposited at the bottom of each tank were collected, dried in open air and weighed. The runoff water was homogenized and an aliquot of $200 \mathrm{ml}$ was taken and dried in an oven at $50^{\circ} \mathrm{C}$ for 72 hours to determine suspended sediment. The suspended sediment in the total runoff volume was added to the bottom sediment weight for Total Soil Loss (PT) using the following formulae (Kouelo, 2016):

$$
\mathrm{PT}=\mathrm{Tf}+\mathrm{Cs}(\mathrm{Vr} / \mathrm{Qa})
$$

Whereas $\mathrm{Tf}=$ sediments deposited at the bottom of the tanks; $\mathrm{Vr}$ = volume of runoff; $\mathrm{Cs}=$ Sediment load and $\mathrm{Qa}=$ the amount of aliquot taken. 
Table 2 Summary of analysis of variance (ANOVA) for various parameters studied in the experiment

\begin{tabular}{|c|c|c|c|c|c|c|c|c|c|c|c|}
\hline \multirow{2}{*}{ Factors } & \multirow{2}{*}{ Runoff } & \multirow{2}{*}{ Soil loss } & \multicolumn{4}{|c|}{ Nutrients loss } & \multicolumn{3}{|c|}{ Textural fractions } & \multicolumn{2}{|c|}{ Organics fraction } \\
\hline & & & $\mathrm{N}$ & $\mathrm{P}$ & $\mathrm{K}^{+}$ & $\mathrm{Mg}^{2+}$ & S & $\mathrm{L}$ & A & POM & MOM \\
\hline Tillage & $* * *$ & $* * *$ & $* * *$ & $* * *$ & $* * *$ & $* * *$ & $* * *$ & $* * *$ & $* * *$ & $* * *$ & $* * *$ \\
\hline Mulching & $* *$ & $* * *$ & $*$ & $* *$ & $*$ & $*$ & $* * *$ & $* * *$ & $* * *$ & $* * *$ & $*$ \\
\hline Tillage vs Mulching & $*$ & $* *$ & $*$ & $* *$ & $*$ & $*$ & $* * *$ & $* * *$ & $* * *$ & $* * *$ & $*$ \\
\hline
\end{tabular}

$*=$ Stands for significant at $\mathrm{p} \leq 0.05 ; * *=$ Stands for significant at $\mathrm{p} \leq 0.01 ; * * *=$ Stands for significant at $\mathrm{p} \leq 0.001$; ns $=$ Stands for no significant ; $\mathrm{N}=$ total nitrogen ; $\mathrm{P}=$ available phosphorus; $\mathrm{K}^{+}=$potassium $; \mathrm{Mg}^{2+}=$ magnesium ; $\mathrm{S}=\mathrm{Sand} ; \mathrm{L}=\mathrm{Loam} ; \mathrm{A}=\mathrm{Clay} ; \mathrm{POM}=$ particulate organic matter ; MOM= fine organic matter.

\subsubsection{Nutrients loss}

Collected sediment was air dried and sieved through a $2 \mathrm{~mm}$ mesh. The sample was further taken for the chemical analysis. Total soil nitrogen content was determined by Kjeldahl method (Jones et al., 1991). Available phosphorus was estimated by using of Bray I method (Bray \& Kurtz, 1945), soil organic carbon was estimated by using the method given by Walkley \&Black (1934), and exchangeable bases $\left(\mathrm{Mg}^{2+}\right.$ and $\left.\mathrm{K}^{+}\right)$were estimated by using the Metson method (1956).

\subsubsection{Mineral and organic constituents of land lost by water} erosion

The fractionation principle used was proposed by Feller (1979). The fractions considered for mineral constituents were clay $(>2 \mu \mathrm{m})$, silt $(2 \mu \mathrm{m}-50 \mu \mathrm{m})$ and sand $(50 \mu \mathrm{m}-2000 \mu \mathrm{m})$. For organic constituents, the fractions used were particulate organic matter $(>50 \mu \mathrm{m})$ and minor organic matter $(<50 \mu \mathrm{m})$. The mineral and organic fractions were dried in an oven at $50^{\circ} \mathrm{C}$ for 72 hours. The organic carbon content of these fractions was determined by the method of Walkley \& Black (1934) modified by Tekalign et al. (1991).

\subsection{Statistical analysis}

Data were subjected to analysis of variance (ANOVA) with two factors, using the general linear model (GLM) procedure of SAS (Version 9.2). Mains effects tested were those of tillage, mulching and interactive effect of these two. Mean were separated using the test of Student-Newman-Keuls at a 5\% probability level.

\section{Results}

\subsection{Runoff and soil loss}

Tillage and mulching effect were significant on runoff and soil loss (Table 2). For tillage, isohypse ridging significantly reduces runoff from $6.27 \%$ (control) to $0.25 \%$ (ridging) and soil loss from $2027.71 \mathrm{~kg} \cdot \mathrm{ha}^{-1} \cdot \mathrm{rain}^{-1}$ (control) to $6.41 \mathrm{~kg} \cdot \mathrm{ha}^{-1} \cdot \mathrm{rain}^{-1}$ (ridging) for an average rainfall of $45 \pm 16.6 \mathrm{~mm}$. Mulching practice also significantly reduces the runoff rate from $6.27 \%$ (control) to $1.77 \%$ (without mulch) and to $0.25 \%$ (with mulch); soil loss from $2027.71 \mathrm{~kg} \cdot \mathrm{ha}^{-1} \cdot$ rain $^{-1}$ (control) to $142.74 \mathrm{~kg} \cdot \mathrm{ha}^{-1} \cdot$.rain $^{-1}$ (without mulch) and to $23.40 \mathrm{~kg} \cdot \mathrm{ha}^{-1} \cdot$.riin $^{-1}$ (with mulch). Interactive effect of tillage and mulching was significant on runoff and soil loss (Table 2). Figures 3 and 4 showed the interactive effect of tillage and mulching. Through these figures, it could be noted that treatment combining isohypse ridging with mulch (T6) has totally reduced the runoff $\left(0 \%\right.$ runoff) and soil erosion $\left(0 \mathrm{~kg}^{-} \mathrm{ha}^{-1} \cdot\right.$.rain ${ }^{1}$ soil lost). Compared to direct seeding without vegetation cover (T1), other treatments also significantly reduced runoff and soil loss. Indeed, treatments that combine one or others tillage modalities with mulching practice (T4, T2) negatively impacted runoff and soil loss. In addition, treatments can be classified in descending order of runoff and soil loss reduction (T6, T5, T4, T2, T3, T1, and T0).

\subsection{Nutrients loss}

Results of study revealed that tillage and mulching significantly ( $p<0.05)$ affected total nitrogen, available phosphorus, exchangeable potassium and magnesium loss (Table 2). In fact, isohypse ridging has reduced nutrients loss under water erosion by around 99\% compared to control. Minimum tillage and no-tillage reduced nutrient loss less than isohypse ridging (Table 4). Mulching practice reduced available phosphorus loss from 0.17 kg.rain ${ }^{-1}$ to $0.002 \mathrm{~kg} \cdot \mathrm{rain}^{-1}$, magnesium loss from $3.32 \mathrm{~kg}$.rain ${ }^{-1}$ to $0.01 \mathrm{~kg} \cdot$ rain $^{-1}$, total nitrogen loss from 4.32 to $0.04 \mathrm{~kg}^{\mathrm{rain}}{ }^{-1}$ and potassium loss from 4.39 to $0.15 \mathrm{~kg} \cdot \mathrm{rain}^{-1}$.

The interactive effect of tillage and mulching was significant on the reduction of total nitrogen, available phosphorus, potassium

and magnesium loss under water erosion. Figures 5, 6, 7 and 8 show the effect of combination of these two factors on nutrients loss. From analyzing these figures, it was reported that isohypse ridging combined to mulching (T6) nullified all nutrients loss 


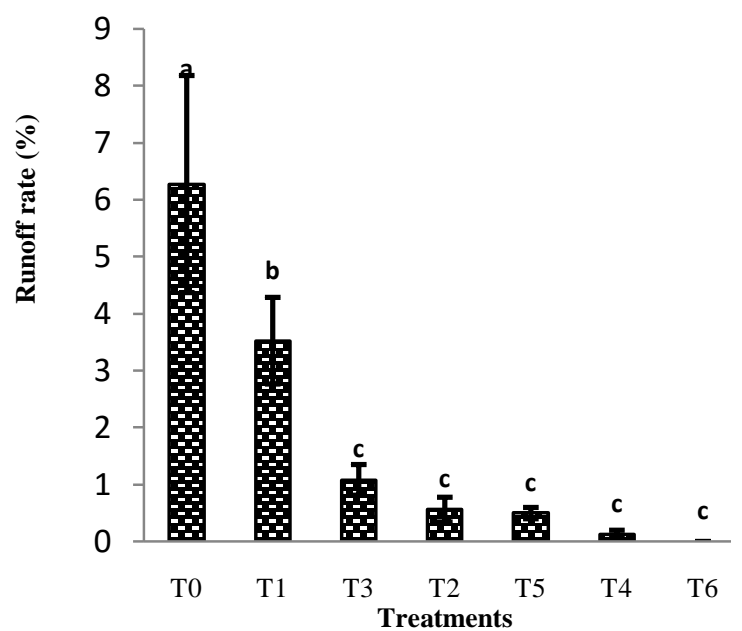

Figure 5 Interactive effect of tillage and mulch on runoff (The bars corresponded to the standard error which represents mean \pm SE. Different letters indicate statistically significant difference)

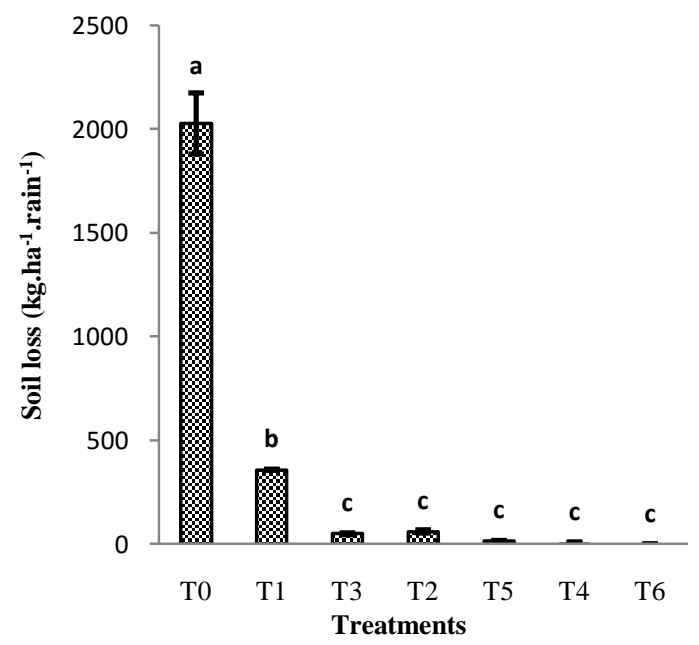

Figure 6 Interactive effect of tillage and mulch on soil loss (The bars corresponded to the standard error which represents mean \pm SE. Different letters indicate statistically significant difference)

$\left(0 \mathrm{~kg}\right.$. rain $\left.^{-1}\right)$. Moreover, mulching practice induced arithmetic reduction of nutrients loss compared to treatments that did not receive mulch. Further, direct seeding combined with mulch (T2) reduced total nitrogen loss by $84 \%$, available phosphorus loss by $86 \%$, potassium loss by $91 \%$ and magnesium loss by $63 \%$ compared to direct seeding without mulch (T1).

\subsection{Mineral Constituents lost under water erosion}

Both tillage and mulching significantly affected soil textural

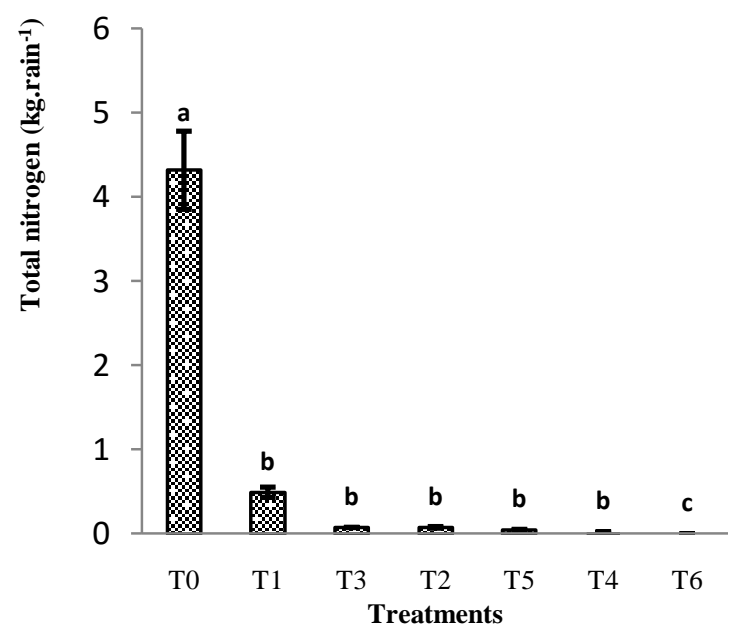

Figure 3 Interactive effect of tillage and mulch on total nitrogen (The bars corresponded to the standard error which represents mean \pm SE. Different letters indicate statistically significant difference)

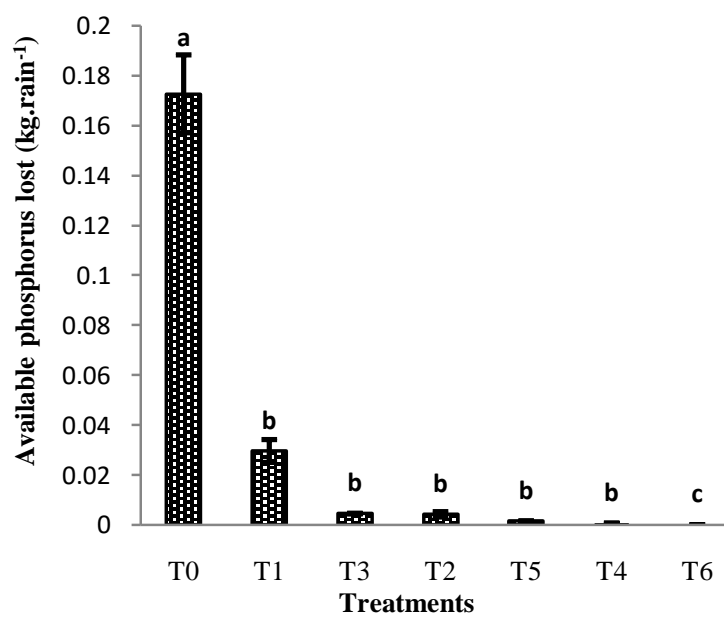

Figure 4 Interactive effect of tillage and mulch on available phosphorus (The bars corresponded to the standard error which represents mean \pm SE. Different letters indicate statistically significant difference)

fractions (sand, silt and clay) (Table 2). On isohypse ridging and no-tillage plots, soil lost contains more clay $(42.44 \%$ and $38.12 \%$ respectively) than sand and silt (Table 4). On plots under minimum tillage and control plot, soil lost contains more sand than silt and clay. Mulching practice has reinforced the effect of tillage. In fact, mulch significantly reduced sand, silt and clay lost through erosion. Clay and sandy fractions were more affected (33.07 and $39.93 \%$ respectively).The combination of soil tillage and mulching significantly affected eroded mineral fractions (Table 2). Analyzing the Table 3, it was reported that isohypse 


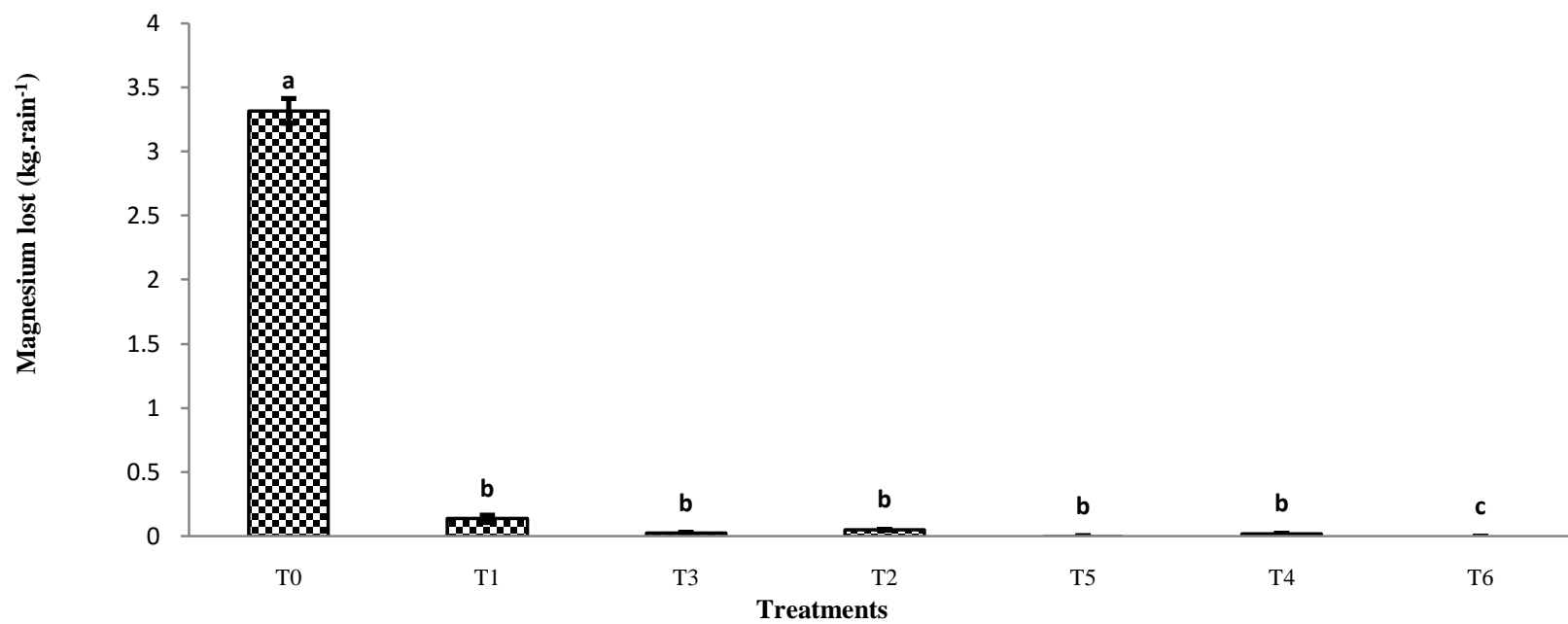

Figure 7 Interactive effect of tillage and mulch on magnesium (The bars corresponded to the standard error which represents mean \pm SE. Different letters indicate statistically significant difference)

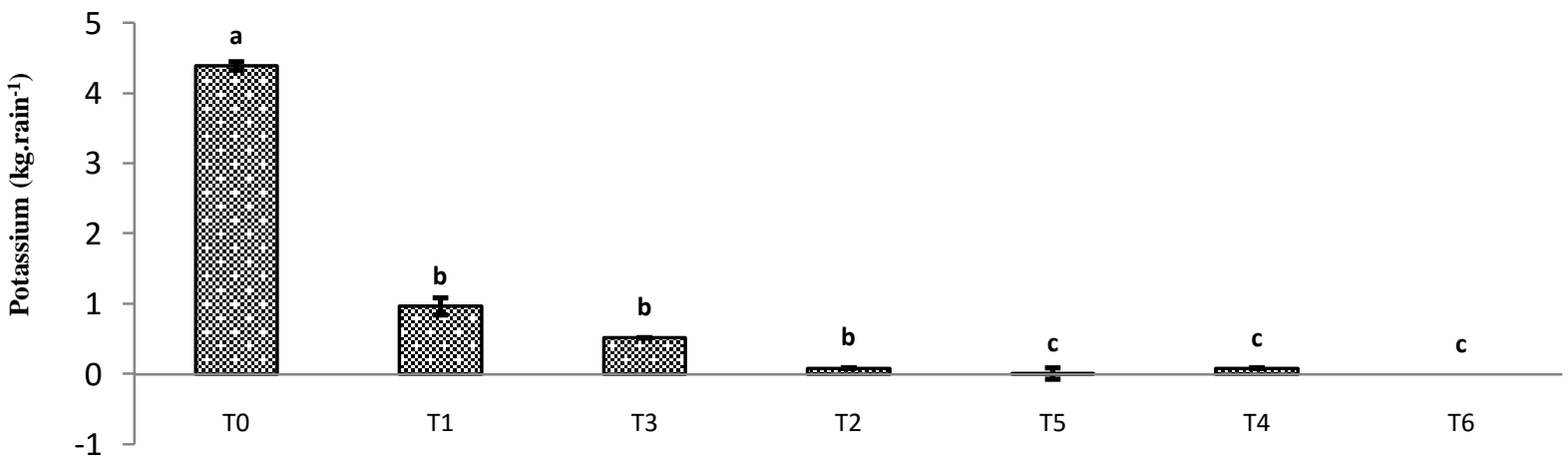

Treatments

Figure 8 Interactive effect of tillage and mulch on potassium (The bars corresponded to the standard error which represents mean \pm SE. Different letters indicate statistically significant difference)

ridge combined with mulch (T6) completely reduced the effect of water erosion. Therefore no soil and textural fractions lost under this treatment. In general, for all treatments, sand and clay fractions are the most affected except under minimum tillage without mulch (T3), which caused more silt loss than clay and sand.

\subsection{Organic Constituents lost under water erosion}

Tillage significantly $(\mathrm{p}<0.05)$ influenced particulate and fine organic matter affected by runoff and associated soil loss (Table 2). In general, results of study (Table 4) revealed maximum
Table3 Interactive effect of tillage and mulching on textural fractions lost by water erosion

\begin{tabular}{|cccc|}
\hline & S & L & A \\
\hline T0 & $42.47 \pm 0.26^{\mathrm{c}}$ & $21.67 \pm 0.31^{\mathrm{b}}$ & $35.86 \pm 0.55^{\mathrm{c}}$ \\
\hline T1 & $37.86 \pm 0.34^{\mathrm{d}}$ & $23.62 \pm 0.38^{\mathrm{b}}$ & $38.52 \pm 0.70^{\mathrm{b}}$ \\
\hline T2 & $35.73 \pm 0.99^{\mathrm{d}}$ & $17.90 \pm 0.51^{\mathrm{c}}$ & $46.36 \pm 0.48^{\mathrm{a}}$ \\
\hline T3 & $30.96 \pm 0.6^{\mathrm{e}}$ & $37.06 \pm 0.94^{\mathrm{a}}$ & $31.99 \pm 1.54^{\mathrm{c}}$ \\
\hline T4 & $54.06 \pm 0.60^{\mathrm{a}}$ & $21.64 \pm 0.59^{\mathrm{b}}$ & $24.63 \pm 0.21^{\mathrm{e}}$ \\
\hline T4 & $47.70 \pm 0.53^{\mathrm{b}}$ & $16.06 \pm 0.27^{\mathrm{c}}$ & $36.24 \pm 0.61^{\mathrm{c}}$ \\
\hline T6 & $0.00 \pm 0.00^{\mathrm{f}}$ & $0.00 \pm 0.00^{\mathrm{d}}$ & $0.00 \pm 0.00^{\mathrm{f}}$ \\
\hline
\end{tabular}

$\mathrm{S}=$ Sand $; \mathrm{L}=$ Loam; $\mathrm{A}=$ Clay, mean $\pm \mathrm{SE}$ value followed by the different letter in same vertical column are significantly different 
Table4: Effect of tillage and mulching on runoff, soil loss, nutrients loss and textural and organic fractions lost by water erosion

\begin{tabular}{|c|c|c|c|c|c|c|c|c|c|c|c|}
\hline \multirow[b]{2}{*}{ Modalities } & \multirow[b]{2}{*}{ Runoff (\%) } & \multirow{2}{*}{$\begin{array}{c}\text { Soil loss } \\
\left(\text { kg.ha }^{-1} \cdot \text {.rain }^{-1}\right)\end{array}$} & \multicolumn{4}{|c|}{ Nutrients loss } & \multicolumn{3}{|c|}{ Textural fractions } & \multicolumn{2}{|c|}{ Organic fractions } \\
\hline & & & $\begin{array}{l}\text { Nitrogen } \\
(\text { kg. rain }\end{array}$ & $\begin{array}{c}\text { Available P } \\
\text { (kg. rain }^{-1} \text { ) }\end{array}$ & $\mathrm{K}^{+} \underset{1}{\left(\mathbf{k g} . \text { rain }^{-}\right.}$ & $\begin{array}{l}\mathrm{Mg}^{2+}(\mathbf{k g} . \\
\left.\operatorname{rain}^{-1}\right)\end{array}$ & $\mathbf{S}(\%)$ & $\mathbf{L}(\%)$ & $\mathbf{A}(\%)$ & $\begin{array}{c}\text { POM } \\
{\left.\text { (kg. } \text { rain }^{-1}\right)}^{-1}\end{array}$ & $\underset{\left(\text { kg. } \text { rain }^{-1}\right)}{\text { MOM }}$ \\
\hline Control & $6.27 \pm 1.33^{\mathrm{a}}$ & $2027.71 \pm 85.05^{\mathrm{A}}$ & $4.32 \pm 0.27^{\mathrm{a}}$ & $0.17 \pm 0.01^{\mathrm{a}}$ & $4.39 \pm 0.27^{\mathrm{a}}$ & $3.32 \pm 0.06^{\mathrm{a}}$ & $42.47 \pm 0.15^{\mathrm{a}}$ & $21.66 \pm 0.18^{\mathrm{b}}$ & $35.85 \pm 0.31^{\mathrm{b}}$ & $490.35 \pm 4.27^{\mathrm{a}}$ & $134.94 \pm 12.05^{\mathrm{a}}$ \\
\hline No tillage & $2.04 \pm 0.70^{\mathrm{b}}$ & $209.97 \pm 66.53^{\mathrm{B}}$ & $0.29 \pm 0.1^{\mathrm{b}}$ & $0.02 \pm 0.006^{\mathrm{b}}$ & $0.79 \pm 0.11^{\mathrm{b}}$ & $0.08 \pm 0.03^{\mathrm{b}}$ & $36.79 \pm 0.54^{\mathrm{b}}$ & $20.76 \pm 1.29^{\mathrm{c}}$ & $42.44 \pm 1.77^{\mathrm{a}}$ & $60.07 \pm 19.82^{\mathrm{b}}$ & $14.25 \pm 4.34^{\mathrm{b}}$ \\
\hline Minimum tillage & $0.60 \pm 0.22^{\mathrm{C}}$ & $25.40 \pm 10.23^{\mathrm{C}}$ & $0.06 \pm 0.01^{\mathrm{b}}$ & $0.003 \pm 0.001^{\mathrm{c}}$ & $0.06 \pm 0.02^{\mathrm{c}}$ & $0.03 \pm 0.01^{\mathrm{b}}$ & $42.51 \pm 5.17^{\mathrm{a}}$ & $29.35 \pm 3.45^{\mathrm{a}}$ & $28.31 \pm 1.69^{\mathrm{c}}$ & $8.17 \pm 2.93^{\mathrm{c}}$ & $1.78 \pm 0.61^{\mathrm{c}}$ \\
\hline Isohypse ridging & $0.25 \pm 0.11^{\mathrm{C}}$ & $6.41 \pm 3.94^{\mathrm{C}}$ & $0.02 \pm 0.01^{\mathrm{b}}$ & $0.0007 \pm 0.0003^{\mathrm{c}}$ & $0.04 \pm 0.03^{\mathrm{c}}$ & $0.01 \pm 0.005^{\mathrm{b}}$ & $33.85 \pm 10.85^{\mathrm{c}}$ & $28.03 \pm 3.59^{\mathrm{a}}$ & $38.12 \pm 8.10^{\mathrm{a}}$ & $2.27 \pm 0.93^{\mathrm{d}}$ & $0.48 \pm 0.22^{\mathrm{c}}$ \\
\hline Control & $6.27 \pm 1.33^{\mathrm{A}}$ & $2027.71 \pm 85.05^{\mathrm{A}}$ & $4.32 \pm 0.27^{\mathrm{a}}$ & $0.17 \pm 0.01^{\mathrm{a}}$ & $4.39 \pm 0.27^{\mathrm{a}}$ & $3.32 \pm 0.06^{\mathrm{a}}$ & $42.47 \pm 0.15^{\mathrm{a}}$ & $21.66 \pm 0.18^{\mathrm{b}}$ & $35.85 \pm 0.31^{\mathrm{a}}$ & $490.35 \pm 4.27^{\mathrm{a}}$ & $134.94 \pm 12.05^{\mathrm{a}}$ \\
\hline No-Mulch & $1.70 \pm 0.49^{\mathrm{B}}$ & $172.60 \pm 66.02 b$ & $0.23 \pm 0.08^{\mathrm{b}}$ & $0.01 \pm 0.004^{\mathrm{b}}$ & $0.42 \pm 0.16^{\mathrm{b}}$ & $0.08 \pm 0.02^{\mathrm{b}}$ & $38.84 \pm 2.43^{\mathrm{b}}$ & $25.58 \pm 3.07^{\mathrm{a}}$ & $35.58 \pm 1.00^{\mathrm{a}}$ & $41.20 \pm 15.86^{\mathrm{b}}$ & $9.32 \pm 3.68^{\mathrm{b}}$ \\
\hline With Mulch & $0.23 \pm 0.1^{\mathrm{C}}$ & $23.40 \pm 9.58 c$ & $0.04 \pm 0.01^{\mathrm{c}}$ & $0.002 \pm 0.0006^{\mathrm{c}}$ & $0.15 \pm 0.09^{\mathrm{b}}$ & $0.01 \pm 0.004^{\mathrm{c}}$ & $39.93 \pm 7.93^{\mathrm{b}}$ & $27.18 \pm 3.34^{\mathrm{a}}$ & $23.67 \pm 6.70^{\mathrm{b}}$ & $5.80 \pm 2.50^{c}$ & $1.69 \pm 0.72^{\mathrm{c}}$ \\
\hline
\end{tabular}

$\mathrm{N}=$ total nitrogen $; \mathrm{P}=$ available phosphorus; $\mathrm{K}^{+}=$potassium $; \mathrm{Mg}^{2}=$ magnesium $; \mathrm{S}=\mathrm{Sand} ; \mathrm{L}=\mathrm{Loam} ; \mathrm{A}=\mathrm{Clay} ; \mathrm{POM}=$ particulate organic matter $; \mathrm{MOM}=$ fine organic matter, mean $\pm \mathrm{SE}$ value followed by the different letter in same vertical column are significantly different 
reduction in particulate organic matter $(\mathrm{POM})$. Indeed, the lowest organic matter loss (for both fractions) was obtained with isohypse ridging. This modality allowed a reduction of particulate and non-particulate organic matter (MOM) of $488.08 \mathrm{~kg}$. rain $^{-1}$ and $134.46 \mathrm{~kg}$. rain $^{-1}$ respectively compared to the control plot (T0). Mulching also significantly influenced particulate and fine organic matter. The presence of mulch allowed $99 \%$ reduction in both organic fractions compared to the control. With this factor, POM was highly affected by water erosion.

The interactive effect of the both tillage and mulching was significant on the particulate and fine fractions of soil organic matter running by erosion ( $\mathrm{p}<0.05$ ). Combination of isohypse and mulch totally reduced soil organic matter loss (for both fractions). In general, treatments received mulch reduced organic matter loss (both fractions) than those that did not receive mulch (Figures 9 and 10).

\section{Discussion}

The results of this study showed that tillage and mulching significantly influenced runoff and soil loss. Isohypse ridging has considerably reduced runoff, soil loss compared to the control. It has significantly reduced (about 99\%) nutrients lost by water erosion for all nutrients compared to the control plot. Mulching practice significantly reduced the loss of phosphorus and magnesium. Further it was reported that nutrient loss increase with runoff and eroded soil quantity. Indeed, ridges constitute obstacles for water whose flow velocity is greatly reduced. Similar results were obtained by Kouelo (2016) who had concluded that no-tillage significantly increase runoff, soil loss and nutrients loss compared to tillage. Kurothe et al., (2014) argued that cultivation practices, especially tillage, constitute an important management tool to combat water erosion risks, to promote in situ water conservation, crop yields improvement and stabilization in rainfed systems in semi-arid and subtropical regions. Residue cover protects soil from degradation caused by raindrops, increases the structural stability of the surface aggregates by increasing soil organic matter content, and creates a strong macro porosity from the surface (Labreuche et al., 2007). Results of this study confirm this fact and have shown that various treatments have significantly reduced runoff, soil loss and nutrients loss compared to the control plot. In addition, treatments combining the mulching practice with tillage have remarkably reduced water erosion compared to those that did not receive mulch. Isohypse ridging combined with mulching canceled runoff, soil loss and nutrients loss. Indeed, this canopy dissipates not only the energy of the raindrops, but also that of the runoff. Heddadj et al. (2005) recognized that tillage combined with significant surface cover reduces water erosion.

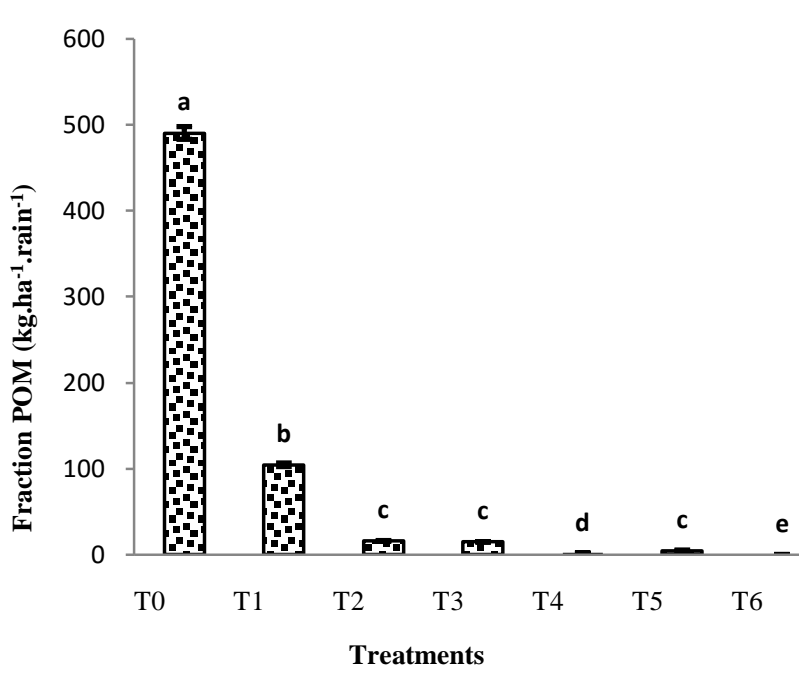

Figure 9Interactive effect of tillage and mulch on particulate organic matter (The bars corresponded to the standard error which represents mean \pm SE. Different letters indicate statistically significant difference)

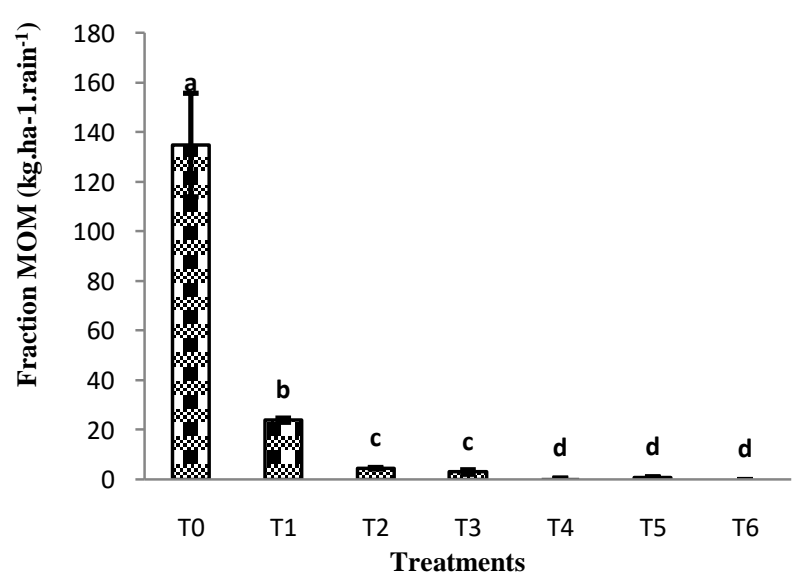

Figure 10 Interactive effect of tillage and mulch on fine organic matter (The bars corresponded to the standard error which represents mean \pm SE. Different letters indicate statistically significant difference)

This study showed that tillage and mulching significantly affected the mineral and organic fractions of the soil lost by water erosion. Indeed, for organic fractions evaluated, it was found that particulate organic matter was the most affected. Indeed, fine organic matter is bound to the soil fine particles, which limits its erosion. Clay and sand fractions are the most eroded. Running soil organic and mineral fractions, erosion acts directly on the soil and the aggregates stability. Isohypse ridging significantly reduced the 
loss of organic fractions. It reduced these losses by more than $200 \%$ compared to the control plot. In fact, ridging by reducing runoff and loss of soil, also reduces the loss of organic fractions. Mulching practice has reinforced this action of isohypse ridging. Its combination with ridging cancels the loss of organic and mineral fractions. Findings of this study were also confirmed by the findings of Blanchart et al. (2004) and Kouelo (2016). Further, Kouelo (2016) had found that carbon losses occur mainly in solid / particulate form and related to bottom and / or suspended soils. But the losses are greatly reduced by vegetation, roughness of the surface of the tilled soil or by mulch or as a result of the reduction of the slope. Blanchart et al. (2004) estimate that carbon losses are negligible in well-covered environments $\left(\sim 50 \mathrm{~kg} \cdot \mathrm{ha}^{-1} \cdot \mathrm{an}^{-1}\right)$ where they are easily compensated by aerosols and especially litter: they have little Influence on the stock of organic matter in the soil. Carbon losses depend heavily on energy sources and the type of erosion.

\section{Conclusion}

Isohypse ridging and mulching constitute two effective practices for the sustainable use and conservation of agricultural soils on low slopes, Findings of this study confirms these facts. Compared to the control, isohypse ridging and mulching can reduced 70 to $80 \%$ soil erosion. Combination of isohypse ridging and mulching can reduced water runoff, soil loss, and nutrient loss up to100\%. The two factors tested significantly influenced the organic and mineral fractions affected by water erosion. In general, the most affected mineral fractions are clay and sand and the most affected organic fraction is particulate. Moreover, the minimum plowing without mulch practice has favored the loss of silt rather than clay and sand. In order to better combat soil degradation through water erosion and the efficient use of water, logging combined with mulching could be useful.

\section{References}

Agossou V, Igué AM (2002) Caractérisation paysanne et scientifique des sols des sites d'expérimentation agricole de la région centre du Bénin. In: Agossou A, Amadji F, Agbo B, Tandjiékpon A (Eds), Actes de l'Atelier Scientifique Centre 1, Dassa Zoumé, Bénin, pp. 136-150.. ISBN 99919-40-12-X.

Baize D, Girard MC (2009) Référentiel pédologique2008. Editions Quae.

Bationo A, Kimetu J, Ikerra S, Kimani S, Mugendi D, Odendo M, Silver M, Swift MJ, Sanginga N (2004) The African network for Soil Biology and Fertility: New challenges and opportunities. Managing Nutrient Cycles to Sustain Soil fertility in Sub-Sahara Africa, Academy Science Publisher, Pp. 1-23.
Benmansour M, Duchemin M, Nouira A, Gallichand J (2006) Emploi combiné des radioéléments, de la modélisation et des mesures aux champs pour étudier l'érosion hydrique des sols en milieu agricole (MAROC-CANADA) : Rapport 2006. Agence Universitaire de la Francophonie et Réseau Érosion \& GCES,Actions en réseau, Convention P2-2092RR621. IRDA, CNESTEN, décembre 2006, Pp. 25.

Blanchart E, Albrecht A, Brown G, Decaens T, Duboisset A, Lavelle P, Mariani L, Roose E (2004) Effects of tropical endogeic earthworms on soil erosion. Agriculture, Ecosystems \&Environment 104: 303-315.

Bray RH, Kurtz LT (1945) Determination of total, organic, and available forms of phosphorus in soils. Soil Science 59: 39-45.

Dabin B (1956) Contribution à l'étude de la fertilité des terres de Barre. L'Agronomie Tropicale 11: 490-506.

Feller C (1979) Une méthode de fractionnement granulométrique de la matière organique des sols. Cahier ORSTOM: Série Pédologie 17: 339-346.

Heddadj D, Gascuel-Odoux C, Cotin P, Hamon Y (2005) Mode de travail du sol, ruissellement et propriétés hydrodynamiques sur un dispositif expérimental de l'Ouest de la France. Etude et Gestion des Sols 12: 53-66.

Henao J, Baanante CA (1999)Estimating rates of nutrient depletion in soils of agricultural lands of Africa (p. 76). Muscle Shoals: International Fertilizer Development Center.

Igué AM (2000) The use of a soil and terrain data base for land evaluation procedures: Case study of Central Benin. $\mathrm{PhD}$ thesis submitted to the University of Hohenheim, Germany, Pp. 235.

Isikwue MO (2005) Influence of nutrients and sediment loads from two rivers in Benue State on crop production. Ph. D Thesis submitted to University of Nigeria, Nsukka.

Jones Jr JB, Wolf B, Mills HA (1991) Methods of Elemental Analysis. In: Plant Analysis Handbook. Micro-Macro Publishing, Inc. 183 Paradise Blvd., Suite 108, Athens, Georgia, Pp. 27-38.

Kouelo Alladassi F (2016) Effets des pratiques culturales sur la dégradation du sol au niveau des trois bassins versants du sud Bénin. Thèse de Doctorat en Sciences Agronomiques, Universités d'Abomey-Calavi, Bénin, 239 pages.

Kurothe RS, Kumar G, Singh R, Singh HB, Tiwari SP, Vishwakarma AK, Sena DR, Pande VC (2014) Effect of tillage and cropping systems on runoff, soil loss and crop yields under semiarid rainfed agriculture in India. Soil \& Tillage Research 140:126-134. 
Labreuche J, LE Souder C, Castillon P, Ouvry JF, Real B, Germon JC, de Tourdonnet S (2007) Evaluation des impacts environnementaux des Techniques Culturales Sans Labour en France. ADEME-ARVALIS Institut du végétal-INRA-APCAAREAS-ITB-CETIOMIFVV.400p.

http://www2.ademe.fr/servlet/getDoc?cid=96\&m=3\&id=51256\& p1=00\&p2=11\&ref=17597; Consulté le 22 juin 2016.

Mazarei M, Ahangar AG (2013) The Effects of Tillage and Geographic Factors on Soil Erosion: A Review. International Journal of Agriculture and Crop Sciences 6: 1024.

Metson AJ (1956) Methods of chemical analysis for soil survey samples. NZ Soil Bur Bull n².

Nyakatawa EZ, Reddy KC, Sistani KR (2001) Tillage, cover cropping, and poultry litter effects on selected soil chemical properties. Soil and Tillage Research 58: 69-79.

Pandey A, Chowdary VM, Mal BC (2007) Identification of critical erosion prone areas in the small agricultural watershed using USLE, GIS and remote sensing.Water Resources Management 21:729-746.

Roose EJ (1967) Dix années de mesure de l'érosion et du ruissellement auSénégal. Agronomie Tropicale 22 : 123-152.

Tekalign T, Haque I, Aduayi EA (1991) Soil, plant, water, fertilizer, animal manure and compost analysis manual. Plant Science Division Working Document 13, ILCA, Addis Ababa, Ethiopia.

Walkley A, Black IA (1934) An examination of the Degtjareff method for determining soil organic matter and a proposed chromic acid titration method. Soil Science 37: 29-38. 